Chirurgia (2020) 115: 554-562

No. 5, September - October

Copyright@ Celsius

http://dx.doi.org/10.21614/chirurgia.115.5.554

\title{
How to Submit a Clinical Paper: Basics, Tips and Traps - Part III
}

\author{
Florin Botea ${ }^{1,2}$, Irinel Popescu ${ }^{1,2^{*}}$ \\ ${ }^{1}$ Center of General Surgery and Liver Transplantation, Fundeni Clinical Institute, Bucharest, Romania \\ ${ }^{2}$ Faculty of Medicine, University "Titu Maiorescu", Bucharest, Romania
}

${ }^{*}$ Corresponding author: Professor Irinel Popescu Center of General Surgery and Liver Transplantation Fundeni Clinical Institute Soseaua Fundeni 258, Bucharest Romania, 022328

E-mail: irinel.popescu220@gmail.com

\section{Rezumat \\ Cum se publică o lucrare științifică: principii, sfaturi, capcane - partea a III-a}

Unul dintre obiectivele principale ale clinicienilor este îmbunătătirea constantă a asistenți medicale, prin transferul de expertiză şi prin implementarea de inovatii. Prin urmare, activitatea publicistică este extrem de importantă. Mai mult, această activitate este poate la fel de importantă şi pentru dezvoltarea carierei academice. Toată lumea medicală, de la studenți la medici seniori, avansează publicând lucrări şi obținând citarea acestora. Învățarea modului optim de a redacta o lucrare ştiințifică şi de a o trimite către revistele de specialitate ar trebui să fie un obiectiv pentru toți studenții, rezidenții, clinicienii şi cercetătorii. Scopul lucrării de față, publicata in trei parti, este de a ajuta pe cei interesați în scrierea şi publicarea în mod eficient a lucrărilor lor ştiințifice; partea a III-a se refera la finalizarea procesul de redactare a unei lucrări ştiințifice şi procesul de trimitere a acesteia spre publicare.

Cuvinte cheie: lucrare ştiințifică, articol clinic, abilități redacționale

\section{Abstract}

One of the main goals of clinicians is to constantly improve the healthcare by spreading their expertise and by introducing innovations in medical science. Therefore, publishing is of utmost importance. Moreover, publishing helps authors in developing their academic carrier. Learning how to properly write and submit a manuscript should be a goal for all medical students, residents, clinicians and researchers. Everyone, from students to senior 
physicians and surgeons, advance in their carrier by publishing papers and by getting their work cited by others. The aim of this paper, published in three parts, is to enable the readers to write and publish their work effectively; the current part is addressing the actual writing workflow of a clinical paper and its submission process to a journal.

Key words: clinical paper, scientific article, writing skills

\section{Finishing to write a quality paper}

Once the body of the paper is written (1) the manuscript is finalized by fulfilling the following steps.

\section{Abstract}

This is the first text to appear un your paper, but should written in the end. It contains the most important ideas of the article, and has to convince the readers that your paper is interesting enough to be read. It must be structured into four paragraphs, i.e., objectives (or background), patients (or materials) and methods, results, and conclusions. Conclusions should be supported by the results of the study, and should satisfy the objectives of the study.

The abstract should not include undefined abbreviations or references to papers in the main text. It is usually limited to $200-300$ words by most journals.

The quality of your abstract will have a great impact on the editor's decision. A good abstract:

- Is accurate (corresponds entirely with the paper's content).

- Can stand alone (as a mini paper).

- Is brief and specific (summarizes the paper's content).

- Is structured according to the journal guidelines.

- The paragraphs are linked in a logical manner.

- Cites no references.

\section{Tips}

- Minimize the use of abbreviations.

- Use active voice whenever possible (makes sentences more readable).
- Pay special attention to the abstract, because most editors and reviewers evaluate the quality of your paper by reading the title, the abstract and the first paragraph of Introduction.

Traps

- Don't use technical jargon.

- Don't use confusing terms.

- Don't include lengthy background information.

- Don't use visual aids (bold, italic, underline fonts, different fonts, font with different sizes, etc).

- Don't write a conclusion based on previous studies and not supported by the present results (common mistake).

\section{Title}

A good title has to include the fewest possible words which effectively define the contents of your manuscript. Indicate the focus of the paper and include important relevant keywords to allow identification of the study through electronic database searches.

Tips

- Attract readers with your title.

- Convey main findings of research, narrow the scope (be specific about what is included in your manuscript).

- Be specific.

- Be concise, short (maximum 16 words).

- Be informative.

- Be complete.

- Use keywords other authors use.

- Put important terms at beginning and end of the title

- Research the journals database, and the journal which you are submitting to, for 
titles on similar topics.

- Revise your title every time you revise your manuscript.

- Remember that most editors and reviewers appreciate the quality by reading the title (along with the Abstract and the first paragraph of Introduction).

Traps

- Don't use unnecessary jargon.

- Don't use abbreviations (except very common abbreviations, like DNA).

- Don't use ambiguous terms.

- Don't use unnecessary details.

- Don't focus on part of the content only.

- Don't use questions or complete sentences.

- Avoid long title (confuses the readers).

- Avoid all redundancies such as "the effects of", "a case of", a comparison of", "observations on", "the nature of", etc.

- Avoid misleading, obscure or exaggerated titles.

Examples:

- "Effect of new antivirals on Patients with HCV-related hepatitis" - POOR (not specific) $\rightarrow$ "Preliminary observations on the effect of new antivirals in Patients with with HCV-related hepatitis" - GOOD.

- "Action of antibiotics on bacteria" POOR (not specific) $\rightarrow$ "Inhibition of growth of streptococcus by streptomycin" - GOOD.

- "Multiple organ transplantation: preliminary results" - POOR (misleading) $\rightarrow$ "Multiple organ transplantation in porcine model: preliminary results".

- "A case study that assesses the impact of ...." - POOR (redundancy, first term is not important) $\rightarrow$ "Assessing the impact of ...".

- "The association between biliary complications and chronic graft rejection in patients transplanted for HCV-related cirrhosis: a four-year longitudinal study" - POOR (redundancy, first term is not important) $\rightarrow$ "Biliary complications and chronic graft rejection in patients transplanted for HCVrelated cirrhosis" - GOOD.

\section{First page (Running title, keywords, word count and correspondence address)}

The title page (first page) should contain a short running title and a few keywords (usually six) to facilitate database searches. Most journals require a word count for the entire article, due to limited length (2000-3000 words). The title page should display a full address of the corresponding author.

\section{Second title page}

The second title page contains the title only, with no author names or institutions; this is used in the review process to ensure that reviewers are unaware of the origin of authors and institutions.

\section{Keywords}

Keywords are essential for indexing, enabling your paper to be easily found, read and cited. Refer to the Guide for authors for journal requirements.

Tips

- Keywords should be specific.

- Avoid unusual abbreviations and general terms, except well-known abbreviations (e.g. DNA).

- Search the Medical Subject Headings (MeSH, National Library of Medicine): http://www.nlm.nih.gov/mesh/MBrowser. html.

\section{Acknowledgements}

Acknowledge everybody who has contributed to the study, but does not meet the criteria for authorship, including:

- Suppliers of materials.

- Financial backers.

- Advisors.

- Typists.

- Proofreaders.

Tips

- State why people have been acknowledged and ask their consent.

- Acknowledge the funding, clearly identifying them. 


\section{References}

Check the style and format as required by the journal's Guide for authors.

The main types are:

- Harvard System (alphabetical by author/date): Baker, MN. 2015, Immunosuppressive regimen in liver transplantation. Un update, Transplantation vol. 41: pp. $141-156$

- APA (American Psychological Association) System (alphabetical): Baker, M.N. (2015). Immunosuppressive regimen in liver transplantation. Un update. Transplantation $41,141^{-156}$

- Vancouver System (numbered in order or citation): Baker MN. Immunosuppressive regimen in liver transplantation. Un update. Transplantation. 2015;41:141-156.

The most common style of references is the Vancouver system.

\section{Tips}

- Respect the Guide for authors.

- Include in the References papers published by the journal you are submitting to.

- Pay attention to the number of authors to list before using "et al."

- Pay attention to the reference style.

- Pay attention to the punctuation.

\section{Traps}

- Avoid using excessive references.

- Avoid citations of unpublished data.

- Avoid too many self-citations.

- Avoid too many citations of papers from the same region.

- Avoid citing papers published only in indigenous language.

- Avoid misspelling of author's names.

\section{Supplementary Materials}

Data related to and supportive of the main text, but of lesser importance, may be included in an appendix that is available online when the manuscript is published. This appendix includes:

- Extensive statistical analysis.

- Extensive tables.

- Any additional data.
- Video data.

\section{The workflow for writing}

\section{Who will write}

When there are several authors, one only must write the paper. Too many writers produce a patchwork of different styles. Authorship, like so many acquired skills, must start early in life. The junior should write, and the senior should revise.

\section{Preparing to write}

- Choose something worthy to report.

- Search the literature and read journals.

- Collect data.

- Write a temporary title.

- Study at the selected journal.

\section{Drafts and revision}

A. First version: in the first version write the maximum information you have in the indicated sequence. The revision can be done at the macrostructure and the microstructure levels (2). The macrostructure revision includes the revision of the organization, content, and flow.

B. First revision: arrange the ideas in their correct sequence. Carefully revise the tables and figures. Examine the whole paper and ask yourself three questions:

- Is the item necessary?

- Is it in the correct section?

- Are all necessary items included?

C. Second revision: discriminate between items of primary and secondary importance, and ask the following questions:

- What can be shortened?

- What can be simplified?

- What can be summarized?

- What can be excluded?

D. Third revision

- Finalize the references.

- Write the abstract.

- Choose the final title.

E. Final version includes the revision at microstructure level, that comprises individual words, sentence structure, grammar, punctuation, and spelling: 
- Quality of content:

o check the consistency of material (logical exposition, the title matches the topic and the content of the paper, the abstract is updated with all the findings).

o check the inclusion of appropriate content (all sections of the paper must include the necessary information)

- Quality of composition: revise and test the style, as every statement must be tested to be expressive, simple and concise. Be sure of the meaning of every word in the paper (3).

- Quality of writing: revise the spelling, grammar and syntax. Check the verb tense. Avoid switching from passive voice to active and vice versa within the same paragraph (misleads and distracts the reader) (4).

- Ask the co-authors to check the manuscript. Also ask a consultant with reviewer experience to read it independently, because when you revise your manuscript it is very easy to read what you think you wrote, not what you actually wrote.

\section{Tips}

- Leave time in between revisions (bottomdrawer technique), in this way your revisions will be more efficient.

\section{Traps}

- Most errors in a manuscript is grammar related.

\section{When you finish the manuscript}

\section{Cover letter}

This is your opportunity to communicate with the editor. Keep it to the point but underline the importance of your work to the journal. This is your chance to persuade the editor that your study deserves to be published, so he would invest his time to review your manuscript. In this letter, include:

- Editor's name - address directly to the editor, not to the journal.

- First sentence - include the title, the author list and the journal name.

- Description (brief) of:

o your expertise.

o the main results of your work.

o the importance of your work.

Tips

- State the purpose and the originality of the manuscript.

- Mention what would make your manuscript is valuable to the journal.

- State the consent of all co-authors.

- Disclose if your manuscript has been rejected before.

- Disclose other special requests, such as conflicts of interest, recommended reviewers, reviewers that should not be involved.

Traps

- Do not summarize your manuscript or repeat the abstract.

\section{Submit the manuscript}

Journals have customized online registering systems for submitting the papers. Knowledge of these systems is essential for properly submitting a paper.

Pay attention to the up-to-date author's guidelines, and also to the charging fees for publication and for colored graphics, if any. Submitting the work may take a few days.

For the peer-reviewed journals, an administrator receives your work and passes to the Editor who chooses 2 or 3 reviewers to check your work, and their evaluations are sent back to the Editor. In case of journals with many submitted articles, an Associate editor is interposed between the Editor and the Reviewers; in this case, the Editor only supervises the process and changes the decisions of the Associate editor only in exceptional situations. Some journals allow you to recommend Editor or Reviewers, but do not warrant their assignment. The entire process is usually blinded (the reviewers do not know who the authors of the paper are) and may take several weeks.

Once the manuscript is ready for submis- 
sion, the authors may contract an agent to manage the submission process. However, the agent selects the papers that is taking charge to submit, rejecting about $40 \%$ of the proposals.

The final decision on your submitted work may be:

- Accepted.

- Minor Revision - involves a high chance for acceptance after revision.

- Major revision - low chance for acceptance, special attention should be payed to the revised version of your work.

- Rejected.

\section{Manuscript acceptance}

In case your paper is accepted, it is a major success as this is not a common outcome. The acceptance rate for the indexed journals varies from $0,25 \%$ to $20 \%$, depending on the journal's rank.

After acceptance, the copyright is typically transferred from the authors to the journal. The corresponding author receives the final proof for final minor corrections, and the final version is then published online as an article in press. It is recommended that this version is also checked; if errors are detected at this point, an erratum needs to be published or even the entire article may be retracted.

\section{Manuscript revision}

Reviewers may ask for minor or major revision of your manuscript.

Study the reviewers' comments and formulate a comprehensive letter of response:

- Respond to all comments.

- When you disagree with a reviewer, formulate a polite, scientific and welldocumented response. Example: „The reviewer is oblivious of the work of Pearls et al. (2014) showing that the ... " $\rightarrow$ "Thank you for your comment. However, we consider that the reviewer should take into account that our finding are supported by the recent work published by Pearls et al. (2014), who showed that ".."

- Indicate the page and line numbers when describing the modifications made in the manuscript.

- Perform additional experiments and/or analysis if required, in order to make the final message of your work stronger.

Tips

- Clearly distinguish your responses from the comments made by the reviewers by using a different font style. Example: "Reviewer's Comments: It would also be good to .... Author's reply: Thank you for the useful suggestion. We agree and we add an appropriate ...".

\section{Traps}

- Avoid repeating the same response; if a similar comment is made by multiple reviewers, state your response once and refer it to all the other reviewers that made the same comment.

- Do not ignore any comment of the reviewers.

\section{Manuscript rejection}

If one journal does not accept your manuscript, you have to take advantage of the feedback. In this way, you will have an improved paper. This is the most important achievement, because you can resubmit it again to the same journal or to another, with higher chance of success.

Tips

- Understand why your manuscript has been rejected.

- Reevaluate your work honestly - will it meet the requirements of the reviewers by adding more data to support your results, or another journal would be more suitable?

- Recommended strategies for submitting to another journal:

o In your cover letter, disclose the fact that your manuscript was rejected and indicate the journal.

o Include the comments of the reviewers and the corresponding modifications that you made to the manuscript. 
o Explain why you consider that this journal is more appropriate for submitting your manuscript.

- If your manuscript doesn't get published after repeated submission, the best way to find the cause is by looking in a mirror.

Traps

- Don't take the rejection personally.

- Don't resubmit to another journal without significant revision of your manuscript according to the comments that lead to rejection

- Don't resubmit without checking the Guide for authors of the new journal (there are always some specific guidelines that differ from a journal to another).

\section{Ethical Issues}

Unethical conduct leads to rejection and even to prohibition from publishing in the journal. This misconduct includes:

- Multiple submissions.

- Redundant publications.

- Plagiarism.

- Data fabrication and falsification.

- Improper use of human subjects and animals in research.

- Improper author contribution.

\section{Multiple submissions}

The editorial process of your manuscripts will be barred if duplicated submissions are uncovered. Competing journals regularly exchange information on ongoing submissions. You should not submit your manuscripts to another journal until the ongoing reviewing process is concluded (without publishing). Previous publication of an abstract related to your manuscript does not prohibit subsequent submission for publication, but full disclosure should be made at submission.

\section{Redundant publication}

Re-publication of a paper in another language is not prohibited, if full disclosure of its original source is made at submission, including details of related papers, even if in a different language or in press.

\section{Plagiarism}

Plagiarism consists in the adoption of ideas, procedures, results or words of others without granting the correct credit, including those acquired by reviewing submitted manuscripts by others (Federal Office of Science and Technology Policy, 1999). Submitting the data or interpretations of others without crediting them, gaining unjustified rewards, is theft. Moreover, this misconduct cancels the motivation of researchers to generate new data and interpretations (Bruce Railsback, University of Georgia, USA).

Plagiarism is a serious offence that lead to paper rejection, academic penalties and termination of employment, that seriously affect the scientific reputation. Unacceptable paraphrasing, even with correct citation, is considered plagiarism. In any case, deception is the distinguishing factor for plagiarism $(5,6)$.

Journals use special software to screen for potential cases of plagiarism. Authors can also access this type of service to check for unintentional plagiarism or self-plagiarism.

\section{Self-plagiarism}

Self-plagiarism means having more than $30 \%$ of two or more of your own published papers matching in text (5). There are 3 types of selfplagiarism (7).:

- publishing two (or more) manuscripts that have the same data but with different words;

- splitting up one larger study into separate publications in order to increase the number of publications, even though the larger study would make more sense or better support the findings (i.e., "salami publications");

- using text from a previously published work in a new work by the same author.

\section{Traps}

Avoid copying and pasting parts of your previous works (this error happens most often in case of Methods). 


\section{Incorrect paraphrasing}

Paraphrasing involves a restatement and of the meaning of a published text using your own words. However, this process must be very accurate, and you should not include in the paraphrased sentence statements that do not actually belong to the cited author. This error is usually done on purpose, in order to support the findings of the submitted manuscript.

\section{Data fabrication and falsification}

Fabrication is making up data or findings that are recorded or reported. Falsification is manipulating research procedures, equipment and/or materials, or changing / omitting data or results that modifies findings of the study. Fabrication and falsification are forbidden in any degree, as "the most dangerous of all falsehoods is a slightly distorted truth" (G.C. Lichtenberg, 1742-1799).

\section{Unethical research}

Studies on human and experiments on animals should respect strict ethical standards included in the revised version in 2000 of the Helsinki Declaration of 1975 (8). If the study described in the manuscript does not meet all these ethical for standards, authors must have the consent of their institutional ethical committee and must clarify the rationale behind their approach.

\section{Improper author contribution}

Authorship should be granted based on:

- Significant contributions to idea of the research, to study design, data acquisition and analysis, and/or interpretation of findings.

- Drafting the article

- Revising the article adding essential intellectual content.

- Final consent for the version to be published.

Other contributors that have participated in any other relevant aspects of the project should be listed in the Acknowledgements section. Check the Guide for authors and the recommendations of the International
Committee of Medical Journal Editors (ICMJE) (http://www.icmje.org).

\section{Conflict of interest}

Dealing with a conflict of interest is a separate ethical issue. It is defined as having a set of conditions that could have a significantly influence the authors in their experimentation and/or data interpretation (9). Having a conflict of interest by itself is not necessarily problematic; the failure to disclose the conflict(s) has ethical implications $(9,10)$. Transparency, disclosure, and peer review are good ways to address conflicts of interest, whether financial or personal in nature (11).

\section{Self-citation}

It is certainly acceptable and even required when referring to previous relevant own published studies, but authors should exercise restraint. Self-citation can artificially boost the academic productivity and, therefore, is unethical. Excessive self-citation is not appreciated by reviewers. Moreover, this practice is incorrect if the citation of work of others may be more appropriate instead of the selfcitation.

\section{Getting Accepted}

Summarizing, these are the most relevant factors that makes a manuscript desired (or not) by journals:

1. Wanted:

- Originality.

- Significant advances.

- Well-written sections of the manuscript.

- Readability.

- Ethical standards.

2. Not wanted:

- No scientific interest.

- Outdated info.

- Insufficient data.

- Duplications.

- Inappropriate/incomplete sections of the manuscript.

\section{Conflict of Interest}

The authors declare no conflicts of interests. 


\section{References}

1. Botea F, Popescu I. How to Write a Clinical Paper: Basics, Tips, Traps - Part II. Chirurgia (Bucur). 2020;115(4):432-440.

2. Belcher WL. Writing Your Journal Article in 12 Weeks: a guide to academic publishing success. Thousand Oaks, CA: SAGE Publications; 2009.

3. Grange RI, Vale J, Williams G, Whitfeld HN. Medical writing. BJU Int 2004:94:225-31.

4. Kallestinova E D. How to Write Your First Research Paper. Yale J Biol Med. 2011;84(3):181-190.

5. Marik PE. Self-plagiarism: the perspective of a convicted plagiarist! Eur J Clin Invest. 2015;45(8):883-7.
6. Bonnell DA, Hafner JH, Hersam MC, Kotov NA, Buriak JM, Hammond PT, et al. Recycling is not always good: the dangers of self-plagiarism. ACS Nano. 2012;6(1):1-4.

7. Mohapatra S, Samal L. The ethics of self-plagiarism. Asian J Psychiatr. 2014;12:147.

8. Altinors N. The structure of a neurosurgical manuscript. Acta neurochirurgica Supplement. 2002;83:115-20.

9. Williams HC. Full disclosure--nothing less will do. The Journal of investigative dermatology. 2007;127(8):1831-3.

10. Johnson TM. Tips on how to write a paper. Journal of the American Academy of Dermatology. 2008;59(6):1064-9.

11. Caplan AL. Halfway there: the struggle to manage conflicts of interest. The Journal of clinical investigation. 2007;117(3):509-10. 